\title{
Cell-wall Proteins of Aspergillus niger and Chaetomium globosum
}

\author{
By A. D. MITCHELL AND I. E. P. TAYLOR \\ Department of Botany, University of British Columbia, Vancouver 8 , \\ British Columbia, Canada
}

(Accepted for publication 8 August 1969)

\begin{abstract}
SUMMARY
Cell-wall fractions were obtained from Aspergillus niger and Chaetomium globosum. Non-structural protein was removed by successive washes in urea, $\mathrm{NH}_{4} \mathrm{OH}$ and formic acid. Amino acid analyses indicated that structural wall proteins were acidic. Aspartic acid was the free amino terminal residue of the protein in both species. Comparison of the 'maps' of peptic peptides indicate that there may be some homology between the wall proteins of the two fungi.
\end{abstract}

\section{INTRODUCTION}

The status of proteins associated with the walls of fungi has been discussed in several recent reviews (Northcote, 1963; Aronson, 1965; Bartnicki-Garcia, 1968). The linkage between carbohydrate and protein components of the wall has been investigated in baker's yeast. Northcote \& Horne (I952) identified a protein + mannan complex, and Falcone \& Nickerson (1956) reported an additional protein + glucan complex. Eddy (1958) postulated that wall protein served to link the insoluble glucan matrix with alkali-soluble mannan and glucan. Sentandreu \& Northcote (1968) identified two types of carbohydrate +amino acid linkages in a yeast cell-wall glycopeptide: $O$-mannosyl linkages to serine and threonine joined low molecular weight sugars to the peptide. Linkage to high molecular weight carbohydrate was between aspartic acid and glucosamine. There is little information about the structure of the wall protein. Numerous qualitative (e.g. Crook \& Johnston, 1962; Ruiz-Herrera, 1967) and quantitative (e.g. Kessler \& Nickerson, 1959; Dyke, 1964; Shah \& Knight, 1968) amino acid analyses have been reported for yeasts and filamentous fungi. Korn \& Northcote (1960) identified glycine and alanine as amino terminal residues, and Nickerson \& Falcone (1956) showed the presence of disulphide bridges in yeast wall protein. The present work reports partial characterization of the wall proteins from two filamentous fungi, Aspergillus niger and Chaetomium globosum.

\section{METHODS}

Organisms. Aspergillus niger (University of British Columbia collection no. 872) and Chaetomium globosum (University of British Columbia collection no. 207) were grown in liquid culture medium containing (g./1.) malt extract 15.0 , yeast extract 0.5 , Difco Soytone 2.5 (R. J. Bandoni, personal communication). Three-week cultures were harvested by filtration on a Buchner funnel and washed with distilled water.

Preparation of cell walls. Washed mycelium was dispersed by homogenization in a Waring blendor at low speed for $5 \mathrm{~min}$. and broken with glass beads ( $200 \mu$ diameter) 
by shaking for 2 min. in water in a Braun MSK homogenizer. The fragmentation was repeated until no whole cells were visible when the preparation was examined with the light microscope. The homogenate was decanted, the beads washed several times with small volumes of distilled water, and the homogenate and washings pooled. The preparation was centrifuged at $700 \mathrm{~g}$ for $30 \mathrm{sec}$. and the supernatant fluid discarded. The pellet was suspended in water and shaken with glass beads in the disintegrator for I min. The wall fragments were recovered by centrifugation at $700 \mathrm{~g}$ for $30 \mathrm{sec}$. The washing procedure was repeated until the supernatant fluid was clear after centrifugation. The walls were then washed in $\mathrm{M}-\mathrm{NaCl}$ and washing repeated until the supernatant fluid was clear. The preparation was purified further by two washes in $8 \mathrm{M}$-urea, one extraction in $8 \mathrm{M}$-urea for $\mathrm{I} 6 \mathrm{hr}$ at $4^{\circ}$, and two washes in $8 \mathrm{M}$-urea. After each wash, the wall fragments were recovered by centrifugation at $16,000 \mathrm{~g}$ for $5 \mathrm{~min}$. The pellet was finally washed 5 times with each of: water, $\mathrm{M}-\mathrm{NH}_{4} \mathrm{OH}$, water, $5 \%(\mathrm{v} / \mathrm{v})$ formic acid in water, water. The walls were dispersed thoroughly in the liquid and then centrifuged at $16,000 \mathrm{~g}$ for $5 \mathrm{~min}$. The final material was lyophilized and stored at $-10^{\circ}$. Walls purified in this way were free from cytoplasmic contamination when examined by light and electron microscopy.

Protein determination was by the method of Lowry, Rosebrough, Farr \& Randall (I95I) as modified by Eggstein \& Kreutz (I955). Protein removed from the walls during purification was determined by using the lyophilized pooled material from each washing step. Urea and sodium chloride were removed by dialysis against running tap water for $48 \mathrm{hr}$ before lyophilization.

Amino acid analysis. Dried-wall preparation (5 to $10 \mathrm{mg}$.) was hydrolysed in vacuo with $5.7 \mathrm{~N}-\mathrm{HCl}\left(0.1 \mathrm{ml} / \mathrm{mg}\right.$.) for $20 \mathrm{hr}$ at $110^{\circ}$ and dried in a vacuum desiccator over $\mathrm{KOH}$ pellets. Quantitative amino acid analysis was done by the method of Piez \& Morris (1960) with a Bio-Cal automatic amino acid analyser.

Identification of the free amino groups of wall protein. The method of Gray \& Hartley (I963) was modified. Dry walls (5 mg.) were suspended in $0.2 \mathrm{ml} .0 . \mathrm{I} \mathrm{M}-\mathrm{NaHCO}_{3}$ and $0.1 \mathrm{ml}$. I-dimethylaminonaphthalene-5-sulphonyl-(DNS-) chloride in acetone (0. I \%, $\mathrm{w} / \mathrm{v}$ ) was added. The mixture was kept at room temperature for $3 \mathrm{hr}$, dried in a vacuum desiccator and hydrolysed with $5.7 \mathrm{~N}-\mathrm{HCl}$ for $6 \mathrm{hr}$ at $110^{\circ}$. DNS-amino acids were identified by chromatography on polyamide sheets (Woods \& Wang, 1967).

Hydrolysis of wall protein with pepsin. Wall material (40 to $100 \mathrm{mg}$.) was suspended in $5 \%(\mathrm{v} / \mathrm{v})$ formic acid with 4 to Io mg. pepsin (Calbiochem. Ltd.) for $24 \mathrm{hr}$ at $25^{\circ}$. The insoluble material was removed by centrifugation.

Peptic peptide maps. Peptides were separated by high voltage paper electrophoresis in an apparatus similar to that described by Michl (I95I). The buffer systems at $\mathrm{pH} 6.5$ and $2 \cdot 0$ were those of Ambler (1963). Complete peptide maps were obtained only after two procedures. Basic and acidic peptides were resolved by electrophoresis in the first dimension at $\mathrm{pH} 6.5$ for $50 \mathrm{~min}$. Resolution of neutral peptides required electrophoresis in this dimension for 180 min. Marker strips were sewn on a new sheet and second dimension electrophoresis for all peptides was at $\mathrm{pH} 2.0$ for $40 \mathrm{~min}$. Cystine bridges were detected by the diagonal procedure of Brown \& Hartley (1963). Peptides were located by dipping papers in cadmium + ninhydrin reagent (Heilmann, Barollier \& Watzke, I957). Maps were tested for tryptophan-containing peptides by spraying with acid Ehrlich reagent (Reddi \& Kodicek, 1953). 


\section{RESULTS}

Preparation of walls. Complete fragmentation of mycelia was achieved after 2 or 3 homogenizations in water. After 5 water washes only traces of cytoplasm were visible by phase contrast microscopy. Some wall material was lost during washes with $\mathrm{NaCl}$ and urea. Less than $2 \%$ of the dry weight of the material dissolved by washing was protein, except after formic acid treatment when protein was 5 to $10 \%$ of the total removed. The final wall preparation from Aspergillus niger contained $\mathrm{I} \cdot 76 \% \mathrm{~N}$, and from Chaetomium globosum $3 \cdot 21 \% \mathrm{~N}$.

Table I. Quantitative amino acid composition of fungal wall hydrolysates

\begin{tabular}{|c|c|c|c|c|}
\hline \multirow[b]{2}{*}{ Amino acid } & \multicolumn{2}{|c|}{ Aspergillus niger } & \multicolumn{2}{|c|}{ Chaetomium globosum } \\
\hline & $\begin{array}{l}\mu \text { g. amino acid } \\
\text { residue } / \mathrm{mg} \text {. } \\
\text { dry wt }\end{array}$ & $\begin{array}{c}\mu \text { mole amino } \\
\text { acid } / 1000 \\
\mu \text { mole }\end{array}$ & $\begin{array}{l}\mu \mathrm{g} . \text { amino acid } \\
\text { residue } / \mathrm{mg} \text {. } \\
\text { dry } w \mathrm{t}\end{array}$ & $\begin{array}{c}\mu \text { mole amino } \\
\text { acid } / \text { I } 000 \\
\mu \text { mole }\end{array}$ \\
\hline Aspartic acid & $I \cdot I 8$ & $89 \cdot 5$ & $5 \cdot 74$ & $104 \cdot 2$ \\
\hline Threonine* & $1 \cdot 27$ & $109^{\circ} 9$ & $6 \cdot 77$ & $139 \cdot 8$ \\
\hline Serine* & $1 \cdot 92$ & I92.8 & $3 \cdot 84$ & $92 \cdot 0$ \\
\hline Glutamic acid & 0.88 & $59 \cdot 5$ & $7 \cdot 53$ & $121 \cdot 7$ \\
\hline Proline & 0.68 & $65 \cdot 4$ & $4 \cdot 62$ & $99 \cdot 3$ \\
\hline Glycine & 0.72 & 110.3 & $2 \cdot 68$ & $98 \cdot 0$ \\
\hline Alanine & $0 \cdot 76$ & $92 \cdot 7$ & $2 \cdot 89$ & $85 \cdot 0$ \\
\hline I/2 Cystine & 0.35 & $29 \cdot 8$ & 0.83 & $16 \cdot 9$ \\
\hline Valine & 0.55 & $48 \cdot 3$ & $2 \cdot 58$ & $54 \cdot 3$ \\
\hline Methionine & 0.34 & $22 \cdot 7$ & 0.43 & $6 \cdot 9$ \\
\hline Isoleucine & 0.26 & $20 \cdot 4$ & $\mathrm{I} \cdot 39$ & $25 \cdot 7$ \\
\hline Leucine & 0.46 & $25 \cdot 3$ & $3 \cdot 25$ & $60 \cdot 0$ \\
\hline Tyrosine & 0.54 & $28 \cdot 8$ & $I \cdot 70$ & $2 \mathrm{I} \cdot 8$ \\
\hline Phenylalanine & 0.52 & $3 I \cdot I$ & $\mathrm{I} \cdot 87$ & $26 \cdot 5$ \\
\hline Lysine & 0.66 & $44 \cdot 9$ & 0.62 & $10 \cdot 0$ \\
\hline Histidine & Trace & Trace & Trace & Trace \\
\hline Arginine & 0.40 & $22 \cdot 5$ & $2 \cdot 82$ & $37 \cdot 7$ \\
\hline Total & I I.49 & - & $49 \cdot 56$ & - \\
\hline
\end{tabular}

Amino acid analyses of walls. These are given in Table I. The totals show I $15 \%$ protein in Aspergillus niger and $4.96 \%$ in Chaetomium globosum walls. Both proteins contained large total amounts of threonine and serine (30 and $23 \%$, respectively). They were also rich in acidic amino acids ( 14.9 and $22.5 \%$, respectively). Methionine was present in walls of both species. The predominant basic amino acid was lysine in $A$. niger and arginine in C. globosum. Histidine was found only in traces.

Amino acid analysis of walls after digestion with pepsin showed that 10 to $20 \%$ of the wall protein was removed. Various amounts of all amino acids were released, except for lysine, which remained almost entirely in the walls.

Free amino groups of wall protein. The DNS-derivatives of aspartic acid and $\epsilon-\mathrm{NH}_{2}$ lysine were the only fluorescent products after 'dansylation' and hydrolysis of the walls of both species.

Peptide maps. Maps of the peptides released by digestion of cell walls with pepsin are shown in Fig. I and 2. In Aspergillus niger (Fig. I $a, 2 a) 6$ basic, 37 acidic, and 25 neutral ninhydrin-positive spots were located. In Chaetomium globosum (Fig. I $b, 2 b$ ) 

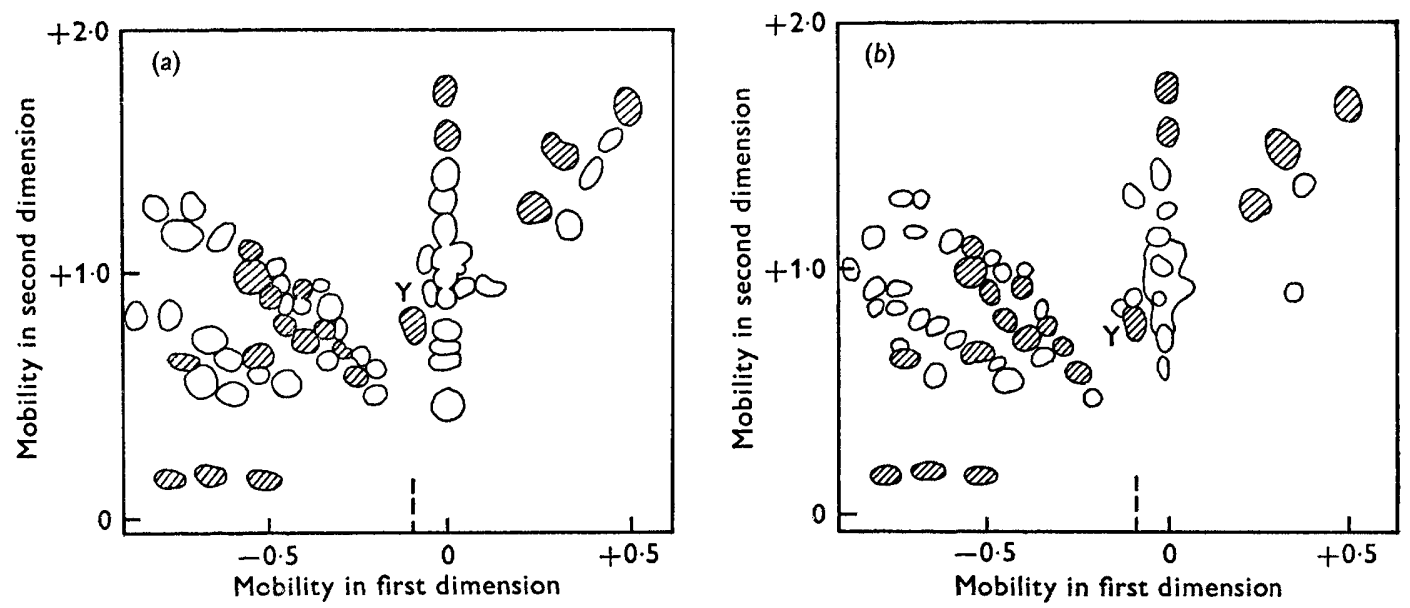

Fig. I. Peptide map of a peptic digest of cell-wall protein of (a) Aspergillus niger, $(b)$ Chaetomium globosum. Electrophoresis was at $\mathrm{pH} 6.5$ in the first dimension (horizontal) and at $\mathrm{pH} 2 \cdot 0$ in the second dimension (vertical). The dashed line marks the origin. Mobilities are relative to aspartic acid $=-\mathrm{I} \cdot \mathrm{O}$ at $\mathrm{pH} 6 \cdot 5$, and $+\mathrm{I} \cdot \mathrm{O}$ at $\mathrm{pH} 2 \cdot 0$. Cross-hatching indicates peptides of identical mobilities from each species. Peptide $\mathrm{Y}$ is the cystine-containing peptide common to both species.
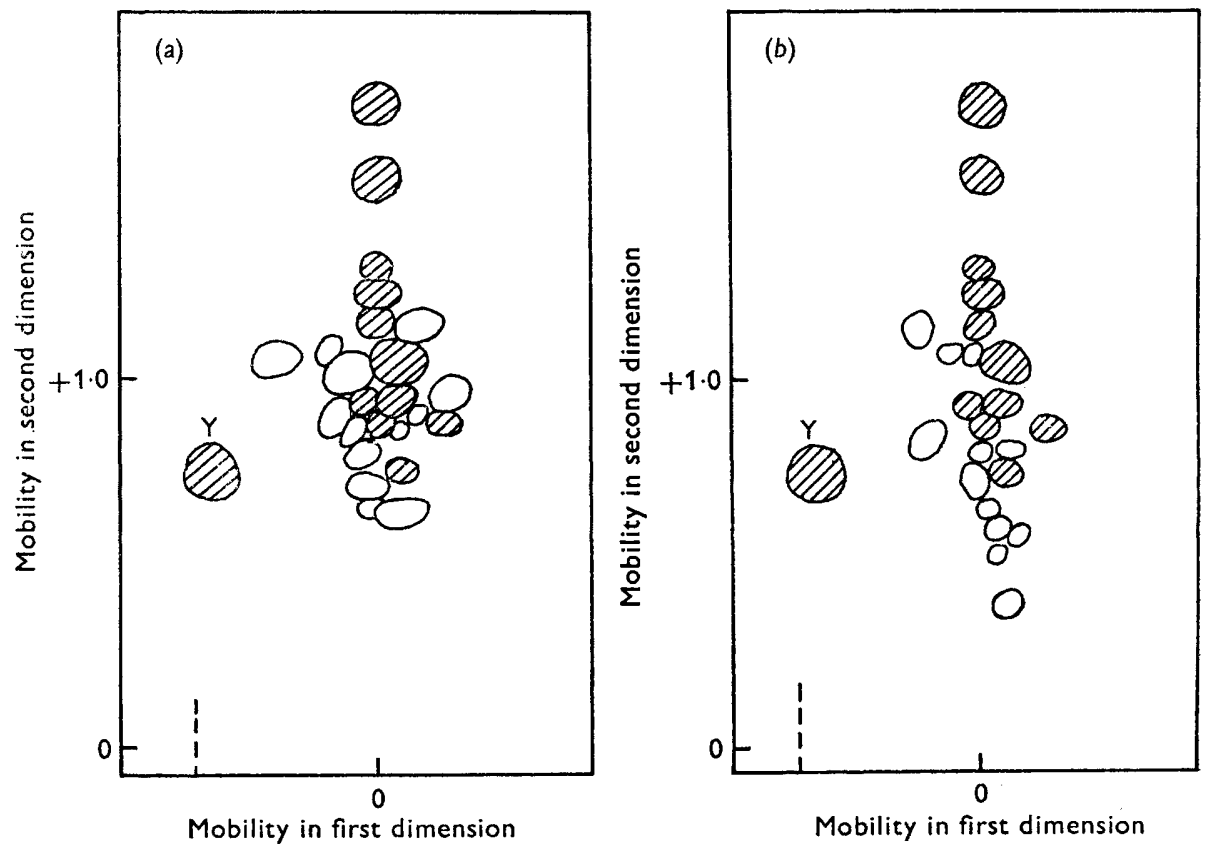

Fig. 2. Map of 'neutral' peptides of a peptic digest of cell-wall protein of (a) Aspergillus niger, (b) Chaetomium globosum. The unresolved peptides (Fig. I) having mobilities approximating to 0 at $\mathrm{pH} 6.5$, were resolved by electrophoresis for $180 \mathrm{~min}$. at $\mathrm{pH} 6.5$ in the first dimension and at $\mathrm{pH} 2 \cdot 0$ in the second dimension. The dashed line marks the origin. Second dimension mobilities are relative to aspartic acid $=+I \cdot 0$. Cross-hatching indicates the peptides of identical mobilities from each species. Peptide $\mathrm{Y}$ is the cystine-containing peptide common to both species. 
there were 5 basic, 37 acidic, and 24 neutral spots. Twenty-nine spots (shaded) showed identical mobilities on maps from both species. In each species 5 pairs of peptides from cystine-containing fragments were located on diagonal maps after performic acid oxidation. Only the pairs derived from spot Y (Fig. I, 2) had the same mobilities in both species. Spot $\mathrm{Y}$ and the peptides derived from it stained orange-yellow with ninhydrin. No peptides containing tryptophan were detected on any of the maps.

\section{DISCUSSION}

Chemical methods for the isolation of cell walls may remove wall constituents (Kreger, 1954). The nature of the final material will vary according to the treatments which have been used in its preparation (Rogers \& Perkins, 1968). Thus, isolated wall preparations cannot sensibly be equated with the functional wall of the whole organism (Crook \& Johnston, I962). In the present work an attempt was made to prepare fungal walls free from all protein which was not an integral part of wall structure. The branched structure of many wall polymers (Setterfield \& Bayley, 196I) could provide a random network in which protein molecules become entangled. The extended exposure to $8 \mathrm{M}$-urea released any protein associated with the wall fragments in this way. Washings with ammonia and formic acid were included to remove protein associated with the wall by adsorption and/or ionic linkage. Reagents which might have caused extensive hydrolysis of peptide bonds or carbohydrate + protein linkages were avoided.

The amino acid analyses given in Table I indicate that the wall proteins of Aspergillus niger and Chaetomium globosum may be acidic and there were many acidic peptides in the peptic digests of the walls (Fig. I). Both proteins were rich in threonine and serine. Other workers (Kessler \& Nickerson, 1959; Dyke, 1964; Chattaway, Holmes \& Barlow, I968) reported similar features in wall proteins from Saccharomyces cerevisiae, Candida albicans and Nadsonia elongata. By using paper chromatography, Crook \& Johnston (1962) did not find methionine in walls of $A$. niger, and recorded it as possibly present in $C$. globosum. We found methionine in small amounts from both of these species. Total $\mathrm{N}$ and total amino acids in the walls of $C$. globosum were higher than in $A$. niger. In $C$. globosum protein N (calculated from amino acid analysis) was $23.6 \%$ of the total N, whereas in $A$. niger it represented only $10 \%$.

The identification of glycine and alanine as amino-terminal residues in yeast wall protein led Korn \& Northcote (1960) to conclude that there may be more than one polypeptide chain present. In Aspergillus niger and Chaetomium globosum aspartic acid was the only free amino-terminal residue in wall protein as determined by dansylation. It is not possible to say at present how many polypeptide chains occur in the structure of wall protein.

Comparison of peptide maps (Fig. I, 2) suggests that there is some homology between the two wall proteins. If the protein plays a vital part in wall structure and in growth, then two regions of homology may be postulated. Similar amino acid sequences would be expected around the points of carbohydrate + protein linkage, for example the linkages through aspartic acid, threonine and serine in yeast (Sentandreu \& Northcote, 1968). Other regions of homology may occur around points of growth control. Nickerson \& Falcone (1956) postulated that fungal wall extension occurred by the action of a protein disulphide reductase on one or more cystine bridges. The 
identification of one cystine bridge (Fig. I and 2, spot Y) which appears similar in both species, leads us to suggest that this is a target for the action of the disulphide reductase.

We thank Drs R. J. Bandoni and T. Bisalputra for their assistance in this work and Dr C. O. Parkes for the amino acid analyses. This work was supported by grants to I.E.P.T. from the National Research Council of Canada and the University of British Columbia.

\section{REFERENCES}

Ambler, R. P. (1963). The amino acid sequence of Pseudomonas cytochrome C-55I. Biochem. J. 89, 349.

Aronson, J. M. (1965). In The Fungi. Ed. by G. C. Ainsworth \& A. S. Sussman, vol. I, p. 49. London and New York: Academic Press.

BARTNICKI-GaRCIA, S. (I968). Cell wall chemistry, morphogenesis and taxonomy of fungi. A. Rev. Microbiol. 22, 87.

Brown, J. R. \& Hartley, B. S. (1963). The disulphide bridges of chymotrypsinogen A. Biochem. $J$. 89, 59 P.

Chattaway, F. W., Holmes, M. R. \& Barlow, A. J. E. (1968). Cell wall composition of the mycelial and blastospore forms of Candida albicans. J. gen. Microbiol. 51, 367.

Crook, E. M. \& Johnston, I. R. (I962). The qualitative analysis of the cell walls of selected species of fungi. Biochem. J. 83, 325 .

DYKe, K. G. H. (1964). The chemical composition of the cell wall of the yeast Nadsonia elongata. Biochim. biophys. Acta 82, 374.

EDDy, A. A. (1958). The structure of the yeast cell wall. II. Degradative studies with enzymes. Proc. $R$. Soc. B $149,425$.

EgGSTEIN, M. \& Kreutz, F. H. (1955). Vergleichende Untersuchungen zur quantitativen Eiweissbestimmung im Liquor und eiweissarmen Lösungen. Klin. Wschr. 33, 879.

FALCONE, G. \& NickeRSON, W. J. (1956). Cell wall mannan-protein of baker's yeast. Science, N. $Y$. $124,272$.

Gray, W. R. \& Hartley, B. S. (1963). A fluorescent end-group reagent for proteins and peptides. Biochem. J. 89, 59 P.

Heilmann, J., Barollier, J. \& Watzke, E. (1957). Beitrag zur Aminosäure bestimmung auf Papierchromatogrammen. $Z$. phys. Chem. 309, 219.

KeSSLER, G. \& NiCKerson, W. J. (I959). Glucomannan-protein complexes from cell walls of yeasts. J. biol. Chem. 234, 228I.

KorN, E. D. \& NoRTHCOTE, D. H. (1960). Physical and chemical properties of polysaccharides and glycoproteins of the yeast cell wall. Biochem. J. 75, I2.

KREGER, D. R. (1954). Observations on cell walls of yeasts and some other fungi by X-ray diffraction and solubility tests. Biochim. biophys. Acta 13, I.

Lowry, O. H., Rosebrough, N. J., Farr, A. L. \& Randall, R. J. (1951). Protein measurement with the Folin phenol reagent. J. biol. Chem. r93, 265.

MichL, H. (I95I). Paper electrophoresis at potential differences of 50 volts per centimetre. Mschr. Chem. 82, 489 .

Nickerson, W. J. \& FALCONE, G. (1956). Enzymatic reduction of disulphide bonds in cell wall protein of baker's yeast. Science, N.Y. 124, 318.

NorthCoTE, D. H. (1963). The biology and chemistry of the cell walls of higher plants, algae and fungi. Int. Rev. Cytol. r4, 223.

NorthCOTE, D. H. \& HORNE, R. W. (1952). The chemical composition and structure of the yeast cell wall. Biochem.J. 51, 232.

Piez, K. A. \& Morris, L. (I960). A modified procedure for automatic analysis of amino-acids. Analyt. Biochem. $\mathbf{1}, \mathrm{I} 87$.

RedDI, K. K. \& KodiceK, E. (I953). Metabolism of nicotinic acid and related compounds in man and rat. Biochem. J. 53, 286.

Rogers, H. J. \& Perkins, H. R. (1968). Cell Walls and Membranes. London: E. and F. N. Spon. 
Ruiz-Herrera, J. (1967). Chemical components of the cell wall of Aspergillus species. Archs Biochem. Biophys. 122, I18.

Sentandreu, K. \& Northcote, D. H. (I968). The structure of a glycopeptide isolated from the yeast cell wall. Biochem. J. rog, 419.

Setterfield, G. \& Bayley, S. T. (1961). Structure and physiology of cell walls. A. Rev. Pl. Physiol. 12, 35 .

ShaH, V. K. \& KNIGHT, S. G. (1968). Chemical composition of hyphal walls of dermatophytes. Archs Biochem. Biophys. 127, 229.

WooDs, K. R. \& WANG, K. T. (1967). Separation of dansyl-amino acids by polyamide layer chromatography. Biochim. biophys. Acta 133, 369. 